\title{
CONCEPTS OF PROFESSIONAL DISCOURSE AS A PROCESS OF COMMUNICATION BETWEEN SCIENTISTS IN PROFESSIONAL SOCIALIZATION
}

\author{
CONCEITOS DE DISCURSO PROFISSIONAL COMO PROCESSO DE \\ COMUNICAÇÃO ENTRE CIENTISTAS EM SOCIALIZAÇÃO PROFISSIONAL
}

\author{
CONCEPTOS DEL DISCURSO PROFESIONAL COMO PROCESO DE \\ COMUNICACIÓN ENTRE CIENTÍFICOS EN LA SOCIALIZACIÓN PROFESIONAL
}

\author{
Dinara Radikovna KOCHEMASOVA ${ }^{1}$ \\ Timur Ravilevich USMANOV ${ }^{2}$ \\ Olga Alexandrovna DANILOVA ${ }^{3}$
}

\begin{abstract}
The concept "discourse" has appeared in connection with expansion of linguistic research out of offer limits - to the sphere of superphrase syntax. Therefore, the discourse from the linguistic point of view is the set consisting of a logical chain of offers which are in semantic communication. This article is devoted to a question of studying of a professional discourse. In the article the concept "professional discourse", among adjacent concepts, is described and defined. In this article the professional discourse, understood as communication of experts among themselves or with those who address them for receiving consultation or the professional help, is studied. Professional communication is opposed to nonprofessional. The discourse plays an important role in professional socialization which is the process by means of which people acquire the specialized knowledge, skills, the relations, norms and interests necessary for effective implementation of the professional roles. The professional discourse is the language created by professionals with special training to perform operations in a workplace. Some scientists consider that it is connected only with communication between the writer and the reader, both which are professionals. Others claim that, at least, one of the participants has to be a professional. For example, some scientists claim that one of the defining characteristics of a professional discourse is the importance of the status in which the person has a professional role and, therefore, higher status than the nonprofessional, that is the reason that the professional discourse usually takes place to be in establishment. Therefore, further in our work we will try to consider questions of a professional discourse in more detail. Articles of Russian and foreign scientists who are engaged in studying this problem will be considered and analyzed.
\end{abstract}

KEYWORDS: Discourse. Model. Language. Profession. Function of language. Approach.

RESUMO: O conceito de "discurso" surgiu em conexão com a expansão da pesquisa linguística fora dos limites de oferta - para a esfera da sintaxe da superfrase. Portanto, o

\footnotetext{
${ }^{1}$ Kazan Federal University (KPFU), Kazan - Russia. Associate Professor of the Department of Foreign Languages. ORCID: https://orcid.org/0000-0001-9225-0792.E-mail: jobdinara@yandex.ru

${ }^{2}$ Kazan Federal University (KPFU), Kazan - Russia. Professor of the Department of Foreign Languages. ORCID: https://orcid.org/0000-0002-7836-7756. E-mail: usmanovtr@mail.ru

${ }^{3}$ Kazan Federal University (KPFU), Kazan - Russia. Senior Lecturer of the Department of Foreign Languages. ORCID: https://orcid.org/0000-0002-0111-884X. E-mail: olgadanilova88@list.ru
} 
discurso do ponto de vista linguístico é o conjunto constituído por uma cadeia lógica de ofertas que se encontram em comunicação semântica. Este artigo é dedicado a uma questão de estudo de um discurso profissional. No artigo o conceito "discurso profissional", em meio a conceitos adjacentes, é descrito e definido. Neste artigo estuda-se o discurso profissional, entendido como comunicação de especialistas entre si ou com aqueles que se dirigem a eles para consulta ou ajuda profissional. A comunicação profissional se opõe à não profissional. O discurso desempenha um papel importante na socialização profissional, que é o processo por meio do qual as pessoas adquirem os conhecimentos especializados, as habilidades, as relações, as normas e os interesses necessários para a efetiva execução dos papéis profissionais. O discurso profissional é a linguagem criada por profissionais com formação especial para realizar operações em ambiente de trabalho. Alguns cientistas consideram que se trata apenas da comunicação entre o escritor e o leitor, ambos profissionais. Outros afirmam que, pelo menos, um dos participantes tem que ser profissional. Por exemplo, alguns cientistas afirmam que uma das características definidoras de um discurso profissional é a importância do status em que está a pessoa que desempenha um papel profissional e, portanto, superior ao do não profissional, razão pela qual o discurso profissional costuma ser prevalente. Portanto, mais adiante em nosso trabalho, tentaremos considerar mais detalhadamente as questões de um discurso profissional. Artigos de cientistas russos e estrangeiros que estão empenhados em estudar este problema serão considerados e analisados.

PALAVRAS-CHAVE: Discurso. Modelo. Linguagem. Profissão. Função da linguagem. Abordagem.

RESUMEN: Los conceptos "discurso" han aparecido en conexión con la expansión de las investigaciones lingüisticas fuera de los límites de la oferta, a la esfera de la sintaxis de superfrase. Por tanto, el discurso desde el punto de vista lingüistico es el conjunto formado por una cadena lógica de ofertas que se encuentran en comunicación semántica. Este artículo está dedicado a una cuestión de estudio de un discurso profesional. En el artículo se describe y define el concepto "discurso profesional" entre conceptos adyacentes. En este artículo se estudia el discurso profesional entendido como la comunicación de los expertos entre sí o con quienes se dirigen a ellos para recibir la consulta o la ayuda profesional. La comunicación profesional se opone a la no profesional. El discurso juega un papel importante en la socialización profesional, que es un proceso mediante el cual las personas adquieren los conocimientos especializados, las habilidades, las relaciones, las normas y los intereses necesarios para la implementación efectiva de los roles profesionales. El discurso profesional es el lenguaje creado por profesionales con formación especial para realizar operaciones en un lugar de trabajo. Algunos científicos consideran que está relacionado solo con la comunicación entre el escritor y el lector, ambos profesionales. Otros afirman que, al menos, uno de los participantes tiene que ser un profesional. Por ejemplo, algunos científicos afirman que una de las características definitorias de un discurso profesional es la importancia del estatus en el que la persona tiene un rol profesional y, por ende, un estatus más alto, que el no profesional, razón por la cual el discurso profesional suele tener lugar. estar en el establecimiento. Por lo tanto, más adelante en nuestro trabajo intentaremos considerar las cuestiones de un discurso profesional con más detalle. En el artículo serán considerados y analizados los trabajos de los cientificos rusos y extranjeros que se ocupan del estudio de este problema.

PALABRAS CLAVE: Discurso. Modelo. Linguaje. Profesión. Función del linguaje. Enfoque. 


\section{Introduction}

The widest concept of a professional discourse is provided by van Dijck who claims that the professional discourse can be divided into three categories. Within a professional discourse or a discourse in a concrete profession, such as communication between scientists. Within a professional discourse or a discourse between natural persons or representatives of different professions, such as communication between the doctors and persons selling pharmaceutical medicine or between accountants and engineers; and a professional and lingual discourse, such as communication between lawyers and their clients, or between advertisers and their potential clients (BAKLASHOVA; ABDULLINA,2018).

The standard professional discourse which is used for regulation or control of a profession is added to these categories. For example, the practice codes given by hospital to doctors and nurses. The standard professional discourse which is usually taking the occluded form has to belong to categories of within-professional or inter-professional discourse. Certainly, the standard discourse can be written by peers or experts of other categories, but there is very considerable difference in comparison with other types of communication, mainly that the standard discourse has very strong standard function in formation and formation of the considered profession. The other important aspect which should be added to conceptualization of a professional discourse is interactive or emotional function of language in professional contexts where interpersonal negotiations on a value are always assigned in addition to exchange of information. At last, the language used by professionals playing an important role in generalization of their professional roles and identities as many claim that the professional discourse is "the licensed belonging" to a profession or "a sign of the personality". As marked out Arutyunov (1990), "the lawyer considers himself the lawyer because he speaks, writes and reads how the lawyer". Training in how to communicate on an equal basis with professionals, always is the first step on the way to a profession. It especially concerns professions which substantially rely on communication, such as representatives of advertizing agency. In brief, the professional discourse can be defined how any semiotics forms - the colloquial, written or visual, made and making social and domain contexts and used by professionals with special preparation for achievement transaction and interactions and also socialization and standard, functions. As the interdependent system connected with ideology and the social relations, the professional discourse can be focused among professional peers and different professionals, be guided by nonspecialists or be used as the regulating force for control of practice of experts. Purpose: modeling of a professional discourse in relation to communicative practice. 


\section{Methods: descriptive method, observation method, analysis}

The analysis of a professional discourse deeply took roots in traditions of teaching English for specific goals in Great Britain and on the European continent and also in teaching composition or rhetoric in the United States. This pedagogical orientation displaced attention from the central questions of the power and domination to more practical values of use or functions. Though there is nothing bad in that, on functional approach to a professional discourse (KOCHEMASOVA, 2016), there are many editions which intensively rise in other related approaches (for example, the Critical analysis of a discourse), they are left without answer or aren't even studied in the analysis of a professional discourse. It is surprising because the most part of our time is spent in a workplace. There are several theoretical assumptions which have to be stated before we continue, such as social constructionism and social practice, socialization and originality and also indexation, reflection and performalivity. Social constructionism and social practice

The language used by any profession is a product of the generalizations and classifications generalized and classified in the historical and historical relation which tend to stereotypic individuals and solutions of problems. From the point of view of a social constructionism a discourse, including even the scientific discourse, is high-selective and social constitutive and is defined as: a set of values, metaphors, representations, images, stories, statements etc. which somehow together create the concrete version of events. In an environment of any object, an event, the person, etc. there can be a set of various discourses, each of which has the history to tell about the world, other way to present it to the world.

In a similar key the discourse is considered as a form of social practice in which users of any discourse don't realize own actions in interaction. They behave as do because it is a way to be and work in this concrete situation. For example, classes were carried out in the traditional Initiation-Response-Follow-up format, it means that teachers always ask questions, subjects etc., and students always answer them that leads to the subsequent acts of teachers. The teachers and pupils build every day this social practice without silent knowledge or outright understanding of a picture, but this model results in a certain subject reality and, therefore, unequal distribution of the power between the teacher and the pupil. Though this book is called "A professional discourse", can be more appropriate to call it "A professional written discourse" because of its dominating attention to written manifestations of a professional discourse. Nevertheless, written texts aren't less interactive, than a colloquial discourse. As approves Ezhova (2011), the written text is a form of social constructivism because authors build mental 
ideas of social contexts, such as audience and force during the written act; writing as social process can formulate or make social contexts; the text can be formed joint effort of group of people; and writers appropriate "consensual values" of writing, thereby creating concrete measurement of social value. As for reading the written document in which there is also a social interaction because the reader has to address at first the text and discuss with the reader the ways suitable for action very similar to the fact that there is in personal an interaction.

The ability to coordinate actions of people trans-locally depends on ability of the text as material thing to be shown in an identical form everywhere where the reader, the listener or the observer can be in her or his corporal being. This constancy of the text which provides standardization of technology of the press made possible historically a possibility of the organization of the public relations irrespective of local time, the place and the personality. The texts of sutural ways of social action organized extra-local to local actions of our surely incarnate lives. Interaction with text readers is built in local settings of work and will organize them (KOCHEMASOVA, 1997).

In other words, written texts should be considered as social action or social practice which happens in certain time of creation of the letter. It is activated again when the reader reads it and as appropriate reacts to it, perhaps, leaving a big gap between production and reception. It is force and weakness of the letter. It can be stored as constant record for a long time, but it is subject to individual use and interpretation though some texts are more ordering, than others. For example, legislative resolutions provide more compulsory force, than opportunities for creativity and individual negotiations. On the other hand, advertising provides more freedom of incompatibility and improvisation according to requirements and contexts (VORONINA, 2009, p. 67). This moment is ignored in many grants of the written analysis of a discourse which assume the fixed reception and influence of the text irrespective of a text character and social contexts in which they are caused as active.

\section{Results of a research, discussion}

The discourse plays an important role in professional socialization which is process by means of which people acquire the specialized knowledge, skills, the relations, norms and interests necessary for effective implementation of the professional roles. The discourse is important here at least for two reasons.

Professional attributes or framework are gained in such a way that, Savelyeva (2002, p. 48) identifies as "mutual interaction" (for example, interaction) and "the general repertoire" (for 
example, the general set of written discourses) in community of practice which in the main set social the practician (the divided repertoires) developed from interaction (mutual participation) pursuing a common goal (joint venture). From this point of view, the written discourse as a form of the joint repertoire risks to be reduced to just products of mutual participation and joint venture. However, though practice cannot consist in structure of the general repertoires, they don't happen in a historical vacuum and always have historical traces of interactions which generate and do them possible. For example, ethical codes are at the same time a product of interaction between professionals and criterion by means of which they measure the behavior against each other. Other reason of importance of a discourse in professional socialization is that the competence of the professional substantially depends on his or her ability to use the special language demanded from him or her in a concrete situation. In other words, the language used by the professional is important for professional identity which he or she demands. The discrepancy between the requirement of identification and the used language is one of obstacles which the beginning professionals should overcome in this process of secondary socialization. Some research were conducted in this process, but its most part is concentrated on colloquial interactions, and is very little made on a specific role of written texts at socialization of different professions. The recent research is one of exceptions and claims that comparing letters of advisers of legal and professional lawyers that formation of the identity of the professional lawyer is dynamic placement of the contradictory and incompatible voices reached by "concealment of tension in the foreground" of one position and allowing others to recede on a background" (BARON, 2002, p. 198). On the other hand, contradictions between the academic and professional roles, between dynamic and synoptic prospect, between partial and impartial prospect and also between abstraction and the specification, are shown in the texts written by law students as beginners.

Additional research such are necessary to identify the text strategy of the settled and beginning experts and, therefore, to compare ideological contradictions of different professions which can become more obvious if to look at beginners writers of which fight between the contradictions and the conflicts inherent in the professions. Interprofessional comparison of text socialization is also important for definition of more universal strategy of socialization. This question is especially important because of our simultaneous multiple member structures some of which cross our professional, institutional and personal communities. On the other hand, during socialization some language practicians can develop to introduce conditions which interfere with a certain practice, emphasizing conflict character of a discourse: both stimulation, and restriction. 
Attributes and the framework inherent in a profession are a part of identity which is possessed by the professional, and the language used by professionals plays an irreplaceable role in creation and indexing of these professional attributes and frames. Use of language is connected with a profession and the personality whom the professional claims that he creates the mutual and unseparable relations. The reason for which the professional speaks and writes definitely consists in what he or she bears or develops the lawful personality who is projected in his or her discourse. In other words, language uses shots and indexes the professional identity, defining as the person perceives, interprets and behaves that can be considered as a part of the most social practice, designating an unconscious role of the personality when forming use of language. This close connection between the personality and social practice is emphasized with J. There is a deep communication between the personality and practice. Development of practice requires creation of community which members can interact with each other and thus to recognize each other as participants. As a result, practice involves negotiations on ways to be a person in this context (NIKISHINA et al., 2019).

In other words, "the identity and practice reflect each other". On the other hand, the professional identity can be conscious or is strategically constructed by means of a discourse by the expert or the beginner though degree of this consciousness is disputable. Nevertheless exactly thanks to such consensus about close interrelation between use of language and professional identity the last researches emphasized importance of identity in development of communicative competence of various professional disciplines, such as scientific disciplines, health care and geology.

\section{Summary}

The professional discourse as social practice is emphasized with the concepts "indexical", "in the conditions of flexibility" and "perfomativity", all from which are rather well-known in literature of linguistic and cultural anthropology. These concepts appeared in the applied analysis of a discourse only recently. The dexicaloty belongs to provocation or the indication of language on various contextual variables and vice versa. The "reflecting" communication between language and a context has to be emphasized because in some areas of the analysis of a discourse, such as pragmatics, a context plays an active role in production and interpretation, without recognizing a role of language users in formation of contexts at the same time. For this reason "context" should be replaced with "contextualization" that means that the context isn't the static phenomenon, and dynamic process of interaction between a 
context and language users. Some contextual measurements "are given" (for example, language of a body and the hint of a contextualization or index markers of contexts) which actively form a context in creation and interpretation of a statement (BALABANOVA, 2018). Though markers of a contextualization or markers of indexation can vary from change of intonation or the choice of a word to rhetorical structure of the whole text, they are important signals of contextual value on which people rely during interaction. On the other hand, some contextual factors "are brought" (for example, the relative status of participants) that means that they are more adapted and it is rather more difficult to conduct negotiations. The second, more theoretical, concern - a reflection. There are two values of a reflection. The first of them treats linguistic statements, and other sense belongs to wider network social the practician which statements are built in. At the level of statements language can be used for structuring, the organization and classification of the language.

Touch devices as a discursive implements for overcoming values of a discourse, are an example of a language reflection (PALUTINA; SABITOVA, 2019). At the level of social practice the reflection belongs to unconscious action of language users for response to the social environment diluting importance of the separate agency in social actions. For example, mixing of genre conventions in a professional discourse isn't considered as conscious effort of language users, but for satisfaction of requirements and direct contexts. This reflexive answer is underlined with the concept of a performativity relating to production of our social and cultural identity by means of creative use of contextual and interactive resources.

\section{Conclusions}

In conclusion we can tell that though professional workers have vocational training, formal and/or informal, their work also demands use of earlier acquired knowledge or skills. Vocational training can vary of several months, in case of office workers, up to several years, in a case with doctors, and includes acquisition of a vernacular. The professional discourse usually is based on some studied repertoires, but not necessarily uses technical terms or difficult sentence structure though some types, such as legal discourse, (as is well-known) are connected with difficult words and sentence structure.

The professional discourse is also based on the fundamental assumptions relating to a profession. For example, doctors do the diagnosis on the basis of the assumptions which never become obvious in the relations between the doctor and the patient. 
It is also important to note the increasing interest of scientists in a subject of a professional discourse recently, we made attempt more specifically and to deeply consider the matter, but the subject of a discourse remains is still interesting and demands further researches and the analysis.

Materials of the paper can represent scientific-philological and practical interest, be useful for students and teachers, as well as experts involved in problems of modern philology and linguistics.

ACKNOWLEDGEMENTS: The work is performed according to the Russian Government Program of Competitive Growth of Kazan Federal University.

\section{REFERENCES}

ARUTYUNOVA, N. D. Discourse: linguistic encyclopedic dictionary. Moscow, 1990.

BAKLASHOVA, T. A; ABDULLINA, L. R. Text approach methodology in translators training (economic discourse) [La méthodologie d'approche du texte économique dans la formation des traducteurs]. XLinguae, v. 11, n. 1XL, p. 19-32, 2018.

BALABANOVA, I. Y. Value-oriented function of advertising texts (on the material of french and russian languages). Kazan Linguistic Jornal, v. 1, n. 3, p. 22-31, 2018.

BARON, N. Alphabet to email: how written english evolved and where it's heading. London: Routledge, 2000. 316 p.

EZHOVA, T. V. Linguistic features of a scientific discourse. Messenger of OGPU, v. 2, n. $58,2011$.

KOCHEMASOVA, D. R. The analysis of techniques and methods of studying of a discourse in linguistics: foreign languages in the modern world. St. Petersburg, 2016. p. 305310 .

NIKISHINA, S. R. et al. The word-formation category displacement causation: mutational and modification semantics of german, russian and tatar verbs. XLinguae, v. 12, n. 1, p. 21 $36,2019$.

PALUTINA, O. G.; SABITOVA, V. E. Information representation in the court discourse. Kazan Linguistics Journal, v. 3, n. 2, p. 85-93, 2019.

SAVELYEVA, V. V. Art text and art world: correlation and organization. Almaty, 2002. 48 p.

VORONINA, E. B. Ways of word formation of names of the international brands. Bulletin of the Vyatka State Humanities University, v. 2, n. 3, p. 65-68, 2009. 


\section{How to reference this article}

KOCHEMASOVA, D. R.; USMANOV, T. R.; DANILOVA, O. A. Concepts of professional discourse as a process of communication between scientists in professional socialization. Rev. EntreLínguas, Araraquara, v. 7, n. esp. 3, e021043, Sep. 2021. e-ISSN: 2447-3529. DOI: https://doi.org/10.29051/el.v7iesp.3.15701

Submitted: 10/01/2021

Required revisions: 20/03/2021

Approved: 23/06/2021

Published: 01/08/2021 